\title{
Lipid Peroxidation and Enzymatic Antioxidants among Breast Cancer Women of African Descent in Sokoto, Nigeria
}

\author{
M. H. Yeldu ${ }^{{ }^{\star}}$, A. Jibrin ${ }^{1}$, A. A. Ngaski ${ }^{1}$, M. B. Bashir ${ }^{2}$, A. S. Mainasara ${ }^{3}$, B. Sani ${ }^{4}$, \\ I. Z. Wasagu' ${ }^{1}$ and G. Aminu ${ }^{1}$ \\ ${ }^{1}$ Department of Chemical Pathology, Faculty of Medical Laboratory Sciences, Usmanu Danfodiyo \\ University, Sokoto, Nigeria. \\ ${ }^{2}$ Department of Surgery, College of Health Sciences, Usmanu Danfodiyo University, Sokoto, Nigeria. \\ ${ }^{3}$ Department of Chemical Pathology and Immunology, College of Health Sciences, \\ Usmanu Danfodiyo University, Sokoto, Nigeria. \\ ${ }^{4}$ Department of Chemical Pathology, Usmanu Danfodiyo University Teaching Hospital, Sokoto,
}

Nigeria.

\section{Authors' contributions}

This work was carried out in collaboration between all authors. Authors MHY, MBB and AAN designed the study and wrote the protocol. Author GA performed the statistical analysis. Author AJ managed the literature searches and wrote the first draft of the manuscript. Authors ASM, BS and IZW managed the analyses of the study. All authors read and approved the final manuscript.

Article Information

DOI: $10.9734 / A R R B / 2017 / 34672$

Editor(s):

(1) Jean-Marie Exbrayat, Universite Catholique de Lyon, France.

(2) George Perry, Dean and Professor of Biology, University of Texas at San Antonio, USA.

Reviewers:

(1) Yogendra Nayak, Manipal College of Pharmaceutical Sciences, Manipal University, India.

(2) Ismail Kucukkurt, Afyon Kocatepe University, Turkey.

(3) Fernanda Maria Machado Maia, Universidade Estadual do Ceará, Brasil. Complete Peer review History: http://www.sciencedomain.org/review-history/19960

Original Research Article

Received $5^{\text {th }}$ June 2017

Accepted $6^{\text {th }}$ July 2017

Published $10^{\text {th }}$ July 2017

\section{ABSTRACT}

Aims: To assess lipid peroxidation and enzymatic antioxidants in breast cancer patients attending Usmanu Danfodiyo University Teaching Hospital, Sokoto-Nigeria.

Study Design: A cross-sectional study was conducted in which patients with confirmed cases of breast cancer and age-and gender-matched apparently healthy individuals were studied. 
Place and Duration of Study: Breast Cancer Clinic, Usmanu Danfodiyo University Teaching Hospital, Sokoto and Department of Chemical Pathology, Faculty of Medical Laboratory Sciences, Usmanu Danfodiyo University, Sokoto, between January, 2015 and December, 2015.

Methodology: We included forty six (46) each of breast cancer women and controls (age range 20 to $\geq 70$ years). Demographic and anthropometric data were obtained using questionnaires administered to each breast cancer patient and control. Serum activities of superoxide dismutase (SOD), catalase (CAT), glutathione Peroxidase (GPX) and serum concentration of malondialdehyde were estimated using standard techniques.

Results: Result indicated significantly $(\mathrm{p}<0.001)$ lower serum activities of SOD $(1.52 \pm 0.03 \mathrm{U} / \mathrm{ml})$, CAT $(1.57 \pm 0.09 \mathrm{U} / \mathrm{ml})$ and GPX $(10.25 \pm 0.29 \mathrm{nmol} / \mathrm{min} / \mathrm{ml})$, while MDA $(21.07 \pm 0.93 \mu \mathrm{l})$ is significantly $(p<0.001)$ higher in breast cancer patients compared with controls $(3.54 \pm 0.06 \mathrm{U} / \mathrm{ml}$, $5.85 \pm 0.10 \mathrm{U} / \mathrm{ml}, 24.53 \pm 0.17 \mathrm{nmol} / \mathrm{min} / \mathrm{ml}$ and $8.88 \pm 0.66 \mu \mathrm{l}$ respectively). With the exception of serum SOD which is significantly $(p<0.001)$ lower as the cancer progresses from stage I to IV, serum activities of CAT, GPX and concentration of MDA were not significantly $(p>0.05)$ different between the stages of the breast cancer. Serum SOD $(1.47 \pm 0.04 \mathrm{U} / \mathrm{ml})$, CAT $(1.39 \pm 0.10 \mathrm{U} / \mathrm{ml})$ and GPX $(9.53 \pm 0.23 \mathrm{nmol} / \mathrm{min} / \mathrm{ml})$ were significantly $(p<0.05, p<0.01$ and $p<0.001$ respectively) lower, while MDA did not differ significantly ( $p>0.05$ ) among the breast cancer patients on therapy compared with those not on therapy $(1.62 \pm 0.07 \mathrm{U} / \mathrm{ml}, 1.99 \pm 0.17 \mathrm{U} / \mathrm{ml}$ and $12.07 \pm 0.54 \mathrm{nmol} / \mathrm{min} / \mathrm{ml}$ respectively).

Conclusion: This study demonstrates that, the breast cancer patients are oxidatively stressed as evidenced by the lower serum activities of antioxidant enzymes and higher malondialdehyde concentration. It is recommended that, breast cancer patients be supplemented with antioxidants in order to prevent the oxidative onslaught by free radicals.

Keywords: Breast cancer; lipid peroxidation; antioxidants; Sokoto; Nigeria.

\section{INTRODUCTION}

Breast cancer is the second leading cause of death after lung cancer [1] and is the most common type of cancer in women and accounts for the highest morbidity and mortality worldwide $[2,3]$. It is second to cancer of the cervix in the North-Western geopolitical zone of Nigeria and also leading in the South-Western geopolitical zone $[4,5]$.

Oxidative stress resulting from excessive production of reactive oxygen species (ROS) and/or decreased antioxidant capacity in the target cells and tissues has been suggested to play a crucial role in the initiation of DNA damage which might ultimately lead to carcinogenesis $[5,6,7,8]$. Major classes of biomolecules, including proteins, lipids and nucleic acids can be modified by ROS, with changes in their molecular structure and function [9]. The main targets of ROS are the polyunsaturated fatty acids located in the cell membranes and their oxidation results in lipid peroxidation. Lipid peroxidation in breast cancer has previously been reported $[7,10]$.

Various cellular defense mechanisms, consisting of non-enzymatic antioxidants (vitamins A, C, E and glutathione) and enzymatic (SOD, CAT and
GPX) are involved in the control of the debilitating effects of ROS production [11].

The increasing global incidence of breast cancer also emphasizes the need to understand the various mechanisms involved in breast tumourigenesis. However, no previous studies have evaluated lipid peroxidation and antioxidant enzymes activities in breast cancer women of African descent in Sokoto, Nigeria. Therefore, the current study measured the serum activities CAT, SOD, GPX and MDA in breast cancer women in Sokoto, Nigeria.

\section{MATERIALS AND METHODS}

\subsection{Study Subjects and Study Area}

A total of ninety two (92) subjects were included in the study. These comprised of 46 women with histologically confirmed cases of breast cancer age range 20 to $\geq 70$ years and 46 age- and gender-matched apparently healthy women monitored as controls. Eligibility criteria for the patients were histologically confirmed breast cancer patients who have started treatment for the tumour, those that were not yet on cancer treatment. Subjects were ineligible if they are known diabetes, liver or renal dysfunction 
(assessed by preliminary screening). The breast cancer patients attending the Breast Clinic of Usmanu Danfodiyo University Teaching Hospital (UDUTH), Sokoto were enrolled in the study. Sokoto State is located in the North-Western Nigeria. It shares borders with Kebbi State (West and South-East), Zamfara State to the West and Niger Republic to the North. Report from the 2013 projection indicated that the state had a population of 4.6 million [12].

\subsection{Study Design}

A cross-sectional study in which patients with confirmed cases of breast cancer and age-and gender-matched apparently healthy individuals were studied. Qualitative and quantitative data were obtained using standard techniques. Confirmed cases of breast cancer patients were consecutively enrolled from the population of breast cancer patients that attended Breast Clinic UDUTH, Sokoto. The breast cancer patients were selected with the help of a Consultant Surgeon in the Breast Clinic based on the satisfaction of the study inclusion criteria.

\subsection{Ethical Approval}

Ethical approval for the study was obtained from the Ethics and Research Committee of Usmanu Danfodiyo University Teaching Hospital (UDUTH), Sokoto. Written informed consent was obtained from all study participants before enrollment.

\subsection{Blood Samples Collection Processing}

and

Blood specimens (about $5 \mathrm{ml}$ each) were taken into plain vacutainer tubes by venepuncture from a prominent vein. The blood specimen were allowed to clot and later centrifuged at $3000 \mathrm{rpm}$ and the sera were carefully harvested into serum bottles and rapidly stored at $-20^{\circ} \mathrm{C}$ until used for biochemical analysis.

\subsection{Measurement of Anthropometric Parameters}

Subjects were weighted with minimum clothing to the nearest $0.1 \mathrm{~kg}$ by using a regularly calibrated weighing health scale; model ZT 120 (manufactured by Seca Gmbh and Co., Germany), while the heights were measured by using a calibrated Stadiometer, model 220 (manufactured by Seca Gmbh and Co.,
Germany). Body mass index (BMI) for each subject was calculated using the following formula: BMI $\left(\mathrm{kg} / \mathrm{m}^{2}\right)=$ Body Weight $(\mathrm{kg}) /$ Height $\left(m^{2}\right)$.

\subsection{Estimation of Biochemical Analytes}

Serum activities of SOD, CAT and GPX were assayed by the methods of $[13,14,15,16]$ using assay Kits procured from Enzo Life Sciences International, Inc. 5120 Butler Pike, Plymouth Meeting, USA. Serum malondialdehyde concentration was estimated by the method of [17] using Lipid hydroperoxide (LPO) assay kit procured from Cayman Chemical Company, Ann Arbor, Michigan, USA.

\subsection{Data Analysis}

The data obtained were analyzed using Microsoft Office Excel 2007 and Statistical Package for Social Sciences (SPSS) version 20. Results were expressed as mean \pm SEM. Group comparisons were made using one-way analysis of variance (ANOVA), paired comparisons were carried out using the Student's t-test. P-value of equal to or less than 0.05 ( $p \leq 0.05$ ) was considered as significant.

\section{RESULTS}

The demographic and socio-economic characteristics of and breast cancer patients and controls (Table 1) indicated that breast cancer occur in women mostly within the age group of $40-49$ years $(45.7 \%)$, most of them were married $(95.7 \%)$ with no formal education $(52.2 \%)$ or unemployed $(58.7 \%)$.

The anthropometric parameters of breast cancer patients and controls are presented in Table 2. The result indicated no significant $(p>0.05)$ differences in the anthropometric parameters between the breast cancer patients and control.

The result of serum activities of antioxidant enzymes and malondialdehyde concentration among breast cancer patients and controls is presented in Fig. 1. The result indicated significantly $(p<0.001)$ lower serum activities of SOD $(1.52 \pm 0.03 \mathrm{U} / \mathrm{ml})$, CAT $(1.57 \pm 0.09 \mathrm{U} / \mathrm{ml})$ and GPX (10.25 $\pm 0.29 \mathrm{nmol} / \mathrm{min} / \mathrm{ml})$, while serum MDA $(21.07 \pm 0.93 \mu \mathrm{l})$ is significantly $(p<0.001)$ higher in breast cancer patients as compared with controls $(3.54 \pm 0.06 \mathrm{U} / \mathrm{ml}, 5.85 \pm$ $0.10 \mathrm{U} / \mathrm{ml}, 24.53 \pm 0.17 \mathrm{nmol} / \mathrm{min} / \mathrm{ml}$ and $8.88 \pm$ $0.66 \mu \mathrm{l}$ respectively). 
Table 1. Demographic and socio-economic characteristics of controls and patients

\begin{tabular}{|c|c|c|c|c|}
\hline \multirow[t]{2}{*}{ Characteristics } & \multicolumn{2}{|c|}{ Controls } & \multicolumn{2}{|r|}{ Patients } \\
\hline & $\mathrm{N}=46$ & Percentage (\%) & $\mathrm{N}=46$ & Percentage (\%) \\
\hline \multicolumn{5}{|l|}{ Age groups (years) } \\
\hline $20-29$ & 1 & 2.2 & 1 & 2.2 \\
\hline $30-39$ & 15 & 32.6 & 8 & 17.4 \\
\hline $40-49$ & 23 & 50.0 & 21 & 45.7 \\
\hline $50-59$ & 3 & 6.5 & 12 & 26.1 \\
\hline $60-69$ & 3 & 6.5 & 3 & 6.5 \\
\hline$\geq 70$ & 1 & 2.2 & 1 & 2.2 \\
\hline \multicolumn{5}{|l|}{ Marital status } \\
\hline Married & 42 & 91.3 & 44 & 95.7 \\
\hline Single & 1 & 2.2 & 0 & 0 \\
\hline Widowed & 3 & 6.5 & 1 & 2.2 \\
\hline Divorced & 0 & 0 & 1 & 2.2 \\
\hline \multicolumn{5}{|l|}{ Tribe } \\
\hline Hausa & 32 & 69.6 & 31 & 67.4 \\
\hline Yoruba & 3 & 6.5 & 2 & 4.3 \\
\hline Fulani & 6 & 13.0 & 7 & 15.2 \\
\hline Igbo & 3 & 6.5 & 2 & 4.3 \\
\hline Others & 2 & 4.3 & 4 & 8.7 \\
\hline \multicolumn{5}{|l|}{ Education level } \\
\hline Tertiary & 13 & 28.3 & 5 & 10.9 \\
\hline Secondary & 7 & 15.2 & 10 & 21.7 \\
\hline Primary & 9 & 19.6 & 7 & 15.2 \\
\hline Non-formal & 17 & 37.0 & 24 & 52.2 \\
\hline \multicolumn{5}{|l|}{ Occupation } \\
\hline Senior civil servant & 6 & 13.0 & 4 & 8.7 \\
\hline Junior civil servant & 9 & 19.6 & 4 & 8.7 \\
\hline Petty Trader & 14 & 30.4 & 11 & 23.9 \\
\hline Unemployed & 17 & 37.0 & 27 & 58.7 \\
\hline
\end{tabular}

Table 2. Anthropometric parameters in breast cancer patients and controls

\begin{tabular}{llll}
\hline Parameters & Controls $(\mathbf{n}=\mathbf{4 6})$ & Breast cancer patients $(\mathbf{n}=\mathbf{4 6})$ & P- value \\
\hline Age $($ years $)$ & $42.43 \pm 1.14$ & $45.37 \pm 1.23$ & 0.083 \\
Weight $(\mathrm{Kg})$ & $61.43 \pm 0.85$ & $57.94 \pm 1.90$ & 0.100 \\
Height $(\mathrm{m})$ & $1.59 \pm 0.01$ & $1.59 \pm 0.01$ & 0.437 \\
BMI $\left(\mathrm{Kg} / \mathrm{m}^{2}\right)$ & $24.19 \pm 0.37$ & $23.05 \pm 0.78$ & 0.188 \\
\hline \multicolumn{2}{r}{ Values are mean \pm standard error of mean; $N=$ number of subjects; $B M I=$ Body mass index; Level of } \\
significance is considered when $p<0.05 ;$ significant differences were not observed when breast cancer patients \\
\multicolumn{2}{r}{ were compared with controls }
\end{tabular}

Serum activities of antioxidant enzymes and malondialdehyde concentration among breast cancer patients based on cancer staging is presented in Table 3. The result indicated that, with the exception of serum SOD which decreased significantly $(p<0.001)$ as the cancer progresses from stage I to IV, the serum activities of CAT, GPX and MDA concentration were not significantly $(p>0.05)$ different between the stages of the breast cancer.

Serum activities of SOD, CAT, GPX and MDA concentration among breast cancer patients based on presence or absence of cancer therapy (Table 4) indicated that, with the exception of serum MDA which did not differ significantly ( $p>0.05$ ) between the breast cancer patients on therapy and those not on therapy, the serum SOD $(1.47 \pm 0.04 \mathrm{U} / \mathrm{ml})$, CAT $(1.39 \pm 0.10 \mathrm{U} / \mathrm{ml})$ and GPX (9.53 $\pm 0.23 \mathrm{nmol} / \mathrm{min} / \mathrm{ml})$ decreased significantly $(p<0.05, \quad p<0.01$ and $p<0.001$ respectively) among the breast cancer patients on therapy as compared with those not on therapy $(1.62 \pm 0.07 \mathrm{U} / \mathrm{ml}, 1.99 \pm 0.17 \mathrm{U} / \mathrm{ml}$ and $12.07 \pm 0.54 \mathrm{nmol} / \mathrm{min} / \mathrm{ml}$ respectively). 


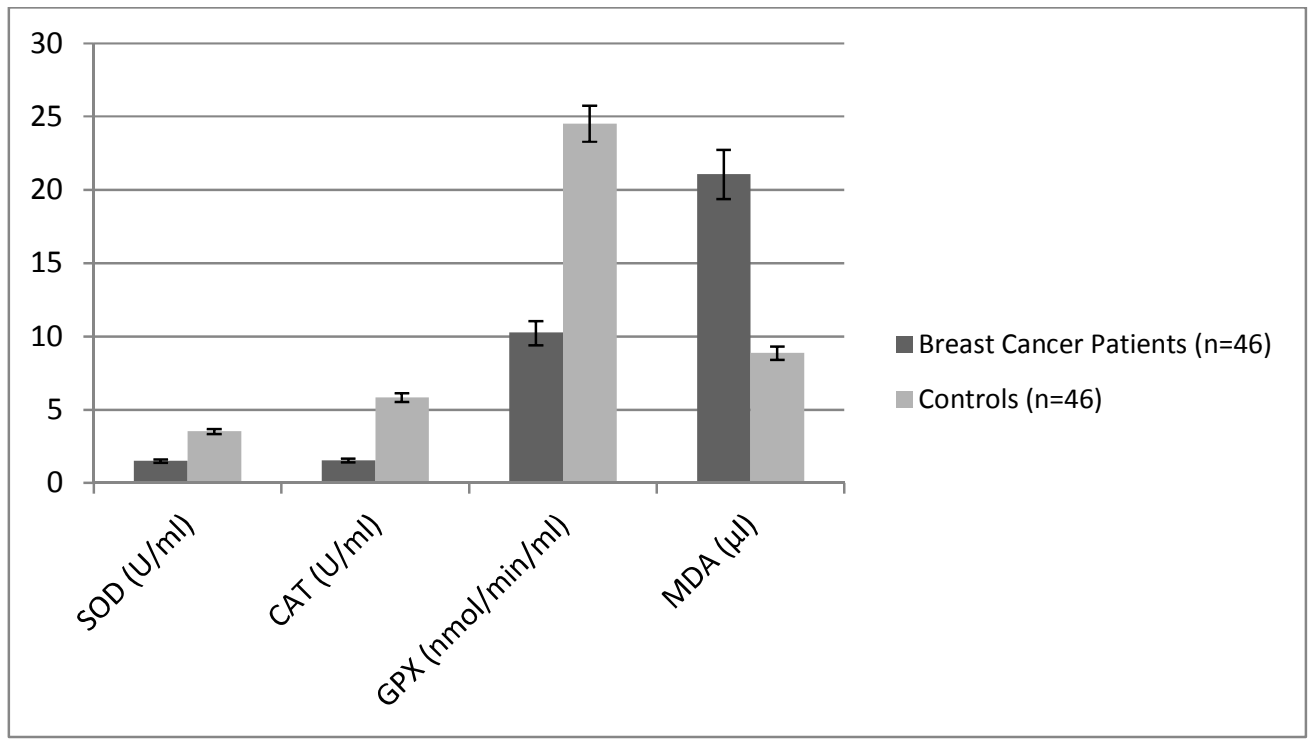

Fig. 1. Serum activities of antioxidant enzymes and malondialdehyde concentration in breast cancer patients and controls

Table 3. Serum activities of antioxidant enzymes and malondialdehyde concentration among breast cancer patients based on cancer staging

\begin{tabular}{|c|c|c|c|c|}
\hline \multirow{2}{*}{$\begin{array}{l}\text { TNM classification } \\
\text { (American Cancer } \\
\text { Society, 2013) }\end{array}$} & \multicolumn{4}{|c|}{ Antioxidant enzymes and malondialdehyde concentration } \\
\hline & SOD (U/ml) & CAT (U/ml) & GPX $(\mathrm{nmol} / \mathrm{min} / \mathrm{ml})$ & MDA $(\mu \mathrm{l})$ \\
\hline Stage I $(n=3)$ & $1.93 \pm 0.03$ & $1.97 \pm 0.02$ & $12.75 \pm 0.35$ & $18.81 \pm 0.66$ \\
\hline Stage II $(n=20)$ & $1.68 \pm 0.02$ & $1.43 \pm 0.11$ & $10.43 \pm 0.43$ & $20.52 \pm 1.70$ \\
\hline Stage III $(n=16)$ & $1.38 \pm 0.01$ & $1.56 \pm 0.17$ & $9.78 \pm 0.50$ & $22.36 \pm 1.46$ \\
\hline Stage IV $(n=7)$ & $1.17 \pm 0.02$ & $1.80 \pm 0.31$ & $9.68 \pm 0.73$ & $23.08 \pm 0.56$ \\
\hline P-Value & 0.000 & 0.377 & 0.086 & 1.000 \\
\hline \multicolumn{5}{|l|}{ Post Hoc Test, LSD } \\
\hline Stage I vs II & 0.000 & 1.000 & 0.323 & 1.000 \\
\hline Stage I vs III & 0.000 & 1.000 & 0.099 & 1.000 \\
\hline Stage I vs IV & 0.000 & 1.000 & 0.141 & 1.000 \\
\hline Stage II vs III & 0.000 & 1.000 & 1.000 & 1.000 \\
\hline Stage II vs IV & 0.000 & 1.000 & 1.000 & 1.000 \\
\hline Stage III vs IV & 0.000 & 1.000 & 1.000 & 1.000 \\
\hline
\end{tabular}

Table 4. Serum activities of antioxidant enzymes and malondialdehyde in breast cancer patients based on presence or absence of therapy

\begin{tabular}{|c|c|c|c|}
\hline \multirow[t]{2}{*}{ Parameters } & \multicolumn{2}{|c|}{ Therapy } & \multirow[t]{2}{*}{$P$ value } \\
\hline & Yes $(n=33)$ & No $(n=13)$ & \\
\hline SOD (U/ml) & $1.47 \pm 0.04$ & $1.62 \pm 0.07$ & 0.043 \\
\hline CAT $(\mathrm{U} / \mathrm{ml})^{\prime}$ & $1.39 \pm 0.10$ & $1.99 \pm 0.17$ & 0.003 \\
\hline $\mathrm{GPX}(\mathrm{nmol} / \mathrm{min} / \mathrm{ml})$ & $9.53 \pm 0.23$ & $12.07 \pm 0.54$ & 0.000 \\
\hline $\operatorname{MDA}(\mu \mathrm{l})$ & $20.86 \pm 1.12$ & $21.61 \pm 1.70$ & 0.720 \\
\hline
\end{tabular}




\section{DISCUSSION}

The peak age of incidence of breast cancer was 40-49 years $\left(5^{\text {th }}\right.$ decade). This is in agreement with the findings from the studies conducted in South Africa [18], Ilorin, Nigeria [19] and Sudan [20] who reported the peak age of incidence of breast cancer at the $5^{\text {th }}$ decade. Our result is in contrast with the report from Norway [21] and among the Philippines [22] in which the peak age of incidence were $6^{\text {th }}$ and $8^{\text {th }}$ decade respectively and also contrasted with the report from Khartoum -Sudan [23] where the peak age was above 50 years. The variation in the peak age of the breast cancer in women may be related to the onset of aetiopathogenesis of breast cancer which have been found to include, early menarche, late menopause, late age at first birth, and other reproductive factors [24].

The decreased serum activity of SOD is consistent with the results in Iran [25], India [26] and Egypt [27]. Lower serum activities of CAT corresponded to the findings of a study [25] in Iran; [26,28] in India; but contrasted with that of other study [29] who reported increased serum activities of CAT in breast cancer patients. The decreased serum activities of GPX in this study agreed with the finding of other study [30] who reported decrease in red blood cell GPX activity in breast cancer patients; but this contrasted with the report of previous studies [29,31] who independently reported increased in GPX activity. These conflicting findings in the activities of SOD, CAT and GPX may be due to differences in the enzymatic assay techniques used.

The decreased in serum activity of SOD as the breast cancer progresses from stage I to stage IV is in agreement with the other study [29]. This may be due to increasing rate of generation and accumulation of ROS during the progression of breast cancer. Serum activities of CAT and GPX were similar between the breast cancer patients and controls which corroborated with previous study [26].

Cancer therapy appeared to be an important factor affecting antioxidant enzymes activities in breast cancer. The decreased serum activities of SOD, CAT and GPX observed in the current study agreed with the report of previous researchers [32,33] who reported lower SOD, CAT and GPX in breast cancer patients on chemotherapy. Cytotoxic drugs have been known to produce highly reactive free radicals
(ROS) during chemotherapy treatment of cancer [33]. This explained the reason behind the decreased serum activities of antioxidant enzymes as they try to counteract the effects of these ROS in breast cancer patients that have started treatment for the cancer. The result of the present study also demonstrated an increase serum MDA in breast cancer patients as compared with controls. Oxidative stress resulting from enhanced lipid peroxidation in the tissue of patients with breast cancer as was demonstrated in the present study has been reported by other studies $[34,35]$. This may be the result of an imbalance between the antioxidant defence system and oxidant status, in favour of the oxidants that promoted the production of MDA.

\section{CONCLUSIONS}

The result confirmed the role of oxidative stress in breast cancer. Serum activities of SOD decrease as the breast cancer progresses from stage I to IV. This study also provides evidence that breast cancer patients undergoing therapy have lower serum activities of SOD, CAT and GPX compared to those not yet on therapy. Therefore levels of these antioxidants should be monitored periodically in breast cancer patients and antioxidant micronutrients supplementation along side with chemotherapy or radiotherapy is suggested. Further studies with more oxidative stress-related analytes are needed to explore the various mechanisms involved in breast tumorigenesis.

\section{COMPETING INTERESTS}

Authors have declared that no competing interests exist.

\section{REFERENCES}

1. Dumitrescu RG, Cotarla I. Understanding breast cancer risk: Where do we stand in 2005? J Cell Mol Med. 2005;9:208-221.

2. Parkin DM, Sitas F, Chinrenje M, Stein I, Abratt R. Cancer in indigenous Africansburden, distribution and trends. Lanc Oncol. 2005;9:683-692.

3. Okobia MN, Bunker $\mathrm{CH}$, Okonofua FE, Osime U. Knowledge, attitude and practice of Nigerian women towards breast cancer: A cross-sectional study. World J Surgic Oncol. 2006;4(11):1-9.

4. Afolayan EAO. Cancer in North Western Region of Nigeria: An update analysis of 
Zaria Cancer Registry Data. Western Nig J Med Sci. 2008;1:37-43.

5. Ogunbiyi JO, Fabowale AO, Ladipo AA. Breast cancer. In: Cancer incidence and top ten cancers in eleven local government areas in Ibadan, Nigeria and its environs, 2004 - 2008. Ibadan M. Alofe (Nig.) Enterprises. 2010;11-17.

6. Halliwell B, Gutteridge JMC. Role of free radicals and catalytic metal ions in human disease: An overview. Methods Enzymol. 1999;186:1-85.

7. Huang CY, Wilson MW, Lay LT, Chow CK, Robertson LW, Glauert HP. Increased 8hydroxydeoxyguanosine in hepatic DNA of rats treated with the peroxisome proliferators ciprofibrate and perfluorodecanoic acid. Cancer Lett. 1994;87:223-228.

8. Halliwell $B$, Zhao $\mathrm{K}$, Whiteman $\mathrm{M}$. The gastrointestinal tract: $A$ major site of antioxidant action? Free Radic Res. 2000;33:819-830.

9. Guyton KZ, Kensler TW. Oxidative mechanisms in carcinogenesis. $\mathrm{Br}$ Med Bull. 1993;49:523-544.

10. Khanzode SS, Muddeshwar MG, Khanzode SD, Dakhale GN. Antioxidant enzymes and lipid peroxidation in different stages of breast cancer. Free Radic Res. 2004;38:81-85.

11. Lopaczynski W, Zeisel SH. Antioxidants, programmed cell death, and cancer. Nutri Res. $2001 ; 21(1-2): 295-307$.

12. United Nations Fund for Population Activities (UNFPA). Population Projection and Health Services in Sokoto State, Nigeria; 2013.

13. Ukenda $H$, Maeda S, Ishii T, Sawamura M. Spectrophotometric assay for superoxide dismutase based on Tetrazolium Salt3-1-(Phenylamino)-Carbonyl-3,4-

Terazolium-Bis(4-Methoxy-6-Nitro)

benzenesulfonic acid hydrate reduction by Xanthine-Xanthine oxidase. Anal Biochem. 1997;251:206-209.

14. Zhou M, Diwu Z, Panchuk-Volothium N, Houghland RP. A stable nonfluorescent derivative of resorufin for the fluorometric determination of trace hydrogen peroxide: Applications in detecting the activity of phagocyte NADPH oxidase and other oxidases. Anal Biochem. 1997;253:162168.

15. Mohanty JG, Jonathan SJ, Schulman ES, Raible DG. A highly sensitive fluorescent micro-assay of $\mathrm{H}_{2} \mathrm{O}_{2}$ release from activated human leukocytes using a dihhydroxyphenoxazine derivative. J Immunol Methods. 1997;202:133-141.

16. Ozdemir G, Ozden M, Maral H, Kuskay S, Cetinalp P, Tarkun I. Malondialdehyde, glutathione, glutathione peroxidase and homocystein level in type 2 diabetic patients with and without microalbuminuria. Ann Clin Biochem. 2005;42:99-110.

17. Mihaljevic B, Katusin-Razem B, Razem D. The evaluation of the ferric thiocyanate assay for lipid hydroperoxides with special consideration of the mechanism aspects of the response. Fre Radic Biol Med. 1996;21:53-63.

18. Parkin DM, Ferlay J, Hamdi-Cheriff $M$, Sitas F, Thomas JO, Wabinga H, Widan SI. Risk factors for breast cancer in South Africa women. IARC Sci Publ. 2003;15(2): 262-267.

19. Afolayan EAO, Ibrahim OOK, Ayilara GT. Cancer patterns in llorin: An analysis of llorin cancer registry statistics. Trop $\mathrm{J}$ Health Sci. 2012;9:42-47.

20. Alawad AA, Alshiekh AA, Alhaj AM. Demographic characteristics and review of patients with locally advanced breast cancer in Sudan. Afr Med J. 2013;4(2):5-8.

21. Longmark F. Cancer in Norway. Cancer Incidence, Mortality, Survival and Prevalence in Norway. Cancer Registry of Norway Institute of Population - Based Cancer Research. 2007;10:17-64.

22. Radaniel MTM, Laudico AV, Lumague MRM, Mapua CA, Patama T, Pukkala E. Cancer in the Philippines Vol IX Part I cancer incidence in 1998-2002. Manila Philippine. Canc Soc. 2008;23:1-69.

23. Mohammed SG, Daoud FM. The effect of chemotherapy on nutritional status of women with breast cancer. Indian J Sci Res. 2013;4(2):1-14.

24. Freddy S, Perkin DM. Part II cancer in indigenous Africans - Causes and control. Canc Oncol. 2008;9:786-795.

25. Negahdar $M$, Djalali $M$, Abtahi $H$, Sadeghi MR, Aghvami T, Javadi E, Layegh $H$. Blood superoxide dismutase and catalase activities in women affected with breast cancer. Iran J Pub Health. 2005;34(3):3943.

26. Prabasheela B, Singh AK, Fathima A, Pragulbh K, Deka NK, Kumar R. Association between antioxidant enzymes and breast cancer. Recent Res Sci Technol. 2011;3(11):93-95. 
27. Shams N, Said SB, Salem TA, El-Shaheed SH, Roshdy S, Abdel-Rahman R. Metalinduced oxidative stress in Egyptian women with breast cancer. J Clin Toxicol. 2012;2:141.

28. Sinha RJ, Singh R, Mehrotra S, Singh RK. Implications of free radicals and antioxidant levels in carcinoma of the breast: A never- ending battle for survival. Indian J Cancer. 2009;46(2):146150.

29. Elbusaifi SFM, Abdalla, MJ, Sheriff DS, EI Saeity SO. Preliminary studies related to oxidant and antioxidant status and Lactate Dehydrogenase (LDH) activity in Libyan breast cancer patients. Aust J Basic Appl Sci. 2013;7(7):234-23.

30. Junior AL, Paz MF, Da Silva LI, Carvalho SC, Sobral AL, Machado KC, Ferreira PM, Styal P, Freitas RM, Cavalcante AA. Serum oxidative stress markers and genotoxic profile induced by chemotherapy in patients with breast cancer: A pilot study. Oxid Med Cell Longev. 2015;215: 2129-2140.
31. Mishra S, Sharma D, Sharma P. Studies of biochemical parameters in breast cancer with or without metastasis. Indian. J Clin Biochem. 2004;19:7-75.

32. EL-Bindary AA, Yahyab RS, EL-Mezayenc $\mathrm{AH}$, Abo Gad Allah HD, Eissa MA. Antioxidants status in breast cancer patients under therapy. American Journal of Research Communication. 2013;1(7): 152-163.

33. Charushila YK, Subodhini AA. Evaluation of serum antioxidants during adjuvant chemotherapy of breast cancer - A prospective observational study. Biochem Analyt Biochem. 2015;4(2):171.

34. Gonenc $A$, Erten D, Aslan S, Akıncı M, Simsek B, Torun T. Lipid peroxidation and antioxidant status in blood and tissue of malignant breast tumor and benign breast disease. Cell Biol Int. 2006;30:376-80.

35. El-Hefny MA, Karimova ST, Afandiev AM. Lipid peroxidation and antioxidant status in breast cancer patients before and after therapy. Med Cairo Univ. 2009;77(3):3742.

(C) 2017 Yeldu et al.; This is an Open Access article distributed under the terms of the Creative Commons Attribution License (http://creativecommons.org/licenses/by/4.0), which permits unrestricted use, distribution, and reproduction in any medium, provided the original work is properly cited.

Peer-review history:

The peer review history for this paper can be accessed here: http://sciencedomain.org/review-history/19960 